\title{
Impact of Globalization on Trends in Entrepreneurship Education in Higher Education Institutions
}

\author{
Norasmah Othman, Nor Hafiza Othman, and Rahmah Ismail
}

\begin{abstract}
With the trend of increasing globalization, entrepreneurship has been receiving more attention from government and educational institutions. Changes in the uncertain world economy have resulted in fewer job opportunities for college graduates, and in response, the government has sought to develop creativity among students through entrepreneurial activities and programs. The question now is, Are the increasing trends of changes and demands for entrepreneurship education due to the impact of globalization? To answer this question, this study examined the impact of globalization on trends in the demand for business and entrepreneurship education and entrepreneurial skills in Malaysia. Questionnaire data were obtained from 306 participants. The participants were randomly selected from the population of administrators in higher education institutions in Malaysia. Data were analyzed using the descriptive statistics method. The findings show that there is an increasing demand for entrepreneurship education and entrepreneurial skills, indicating that globalization has influenced the demand for entrepreneurship education and entrepreneurial skills among university graduates.
\end{abstract}

Index Terms-Globalization, higher education, entrepreneurship education, entrepreneurial skills.

\section{INTRODUCTION}

Globalization has demanded a more competitive, knowledgeable, creative, and innovative workforce, and Malaysia's education system has adapted to meet this need [1]. In the era of globalization, terms such as knowledge society, knowledge workers, and knowledge economy (k-economy) have added a new paradigm to the field of knowledge, especially for higher education institutions (HEIs) [2], [3] states that switching to a k-economy is a necessary transformation in the era of globalization, as economic competition among countries is expected to intensify. In order for a nation to compete in a globally competitive economy, HEIs play an important role in the development of knowledge and human capital.

The globalized world economy has resulted in an increasingly challenging demand for college graduates to be competitive and creative. Thus, it is essential to ensure that HEIs successfully transmit the appropriate, quality knowledge and skills needed to make the Malaysian

Manuscript received June 10, 2012; revised July 10, 2012.

N. Othman is with the Faculty of Education, University Kebangsaan Malaysia, Bangi, Selangor, Malaysia (e-mail: lin@ukm.my).

N. H. Othman is with the Faculty of Education, University Kebangsaan Malaysia, Bangi, Selangor, Malaysia (e-mail: hafizaothman@yahoo.com).

R. Ismail is with the Faculty of Economy and Management, University Kebangsaan Malaysia, Bangi, Selangor, Malaysia (e-mail: rahmah@ukm.my). workforce "world class human capital" [4]. Governance variables play a vital role in shaping people's perception of various aspects of the economy and society [5]. Under the Tenth Malaysia Plan, the government is committed to developing creativity through efforts to incorporate elements of entrepreneurial innovation into the school curriculum, focusing on R\&D. It also aims to increase the availability of risk capital [6]. These moves reflect that countries around the world are realizing the significance of entrepreneurship and the importance of adopting it as a means to boost employment and economic development [5].

Furthermore, changes in an uncertain world economy have resulted in fewer job opportunities for college graduates. The number of unemployed persons in Malaysia increased from 385,300 in 2009 to 391,400 in 2010 [8]. Thus, the problem of unemployment among graduates is far from underestimated, and it presents a significant challenge for HEIs [9]. HEIs need to create human capital to better prepare job seekers for the global market.

Several studies have shown that entrepreneurship has been identified as a potential catalyst for expanding economic growth [5], [11], [12] and maintaining competitiveness in the face of globalization [13]. The government supports graduates' involvement in entrepreneurship as a means of reducing the country's unemployment rate. This effort can be implemented through education, training, and lifelong learning [14]. According to [12], [16], one approach to developing human capital is to implement entrepreneurship education and training. This study aims to observe the impact of globalization on the demand trends in business and entrepreneurship education and to identify differences in these demands according to specific fields/programs of higher education. Further, it aims to uncover trends in the importance in entrepreneurship skills before and after globalization.

\section{DEVELOPMENT OF ENTREPRENEURSHIP EDUCATION}

The importance of entrepreneurs to the national economic system has led to the importance of entrepreneurship education in today's schools. Entrepreneurship is the process of innovation in economic organizations that either introduces new products or diversifies markets [17]. Thus, entrepreneurship education not only plays a critical role in business education, but is also the contributing factor to the development of quality human capital because it fosters workers' ability to apply and explore new skills and technology. Entrepreneurship training, including relevant courses and programs, is implemented by educational institutions and government agencies. The effort to establish 
such training began in the 1980 s with increases in the offerings of entrepreneurship courses and programs, especially in some developed countries, such as the United States and European countries [18]. According to a study by [19], 25 journal articles have been published on international entrepreneurship to date, and more than 12,000 articles appear each year in various disciplines.

The Ministry of Education (MOHE) has long conducted entrepreneurship acculturation in schools. These activities begin as early as primary school, for example, through the introduction of elements of entrepreneurship in mathematics. The emphasis on entrepreneurship education in secondary schools can be seen in the requirement that students study Integrated Living Skills, which include components on commerce and entrepreneurship. The effort continues in upper secondary school, when students are given the opportunity to choose Commerce and Entrepreneurship Education as elective subjects in vocation and technology [20]. As universities all over the world recognize the importance of entrepreneurship education, many have begun to implement it.

In Malaysia, most public universities offer an entrepreneurship course as a core subject at the first degree level. The introduction of this course to all students is in line with the education goals of the HEIs, designed to assist the economic development of the country: first is to develop human potential by providing training in various fields; second is to create a trained group that will later serve as the nation's human capital [21]. In addition, the MOHE has launched the Entrepreneurship Development Policy for Institutes of Higher Education to encourage the development of human capital, namely, graduate entrepreneurs. The main goal of this policy is to produce quality human capital consisting of graduates who possess the attributes and values of entrepreneurship [22].

\section{RELATIONSHIP BETWEEN GENERIC SKILLS AND ENTREPRENEURSHIP EDUCATION}

HEIs should become the most suitable places for students to develop generic skills. Generic skills are among the elements identified as critical in the globalized workforce, especially given the rapid pace of technological change. They include communication skills, critical thinking and problem-solving skills, teamwork skills, learning and information management, entrepreneurial skills, ethics and morality, and professional management skills. Entrepreneurial skills involve the ability to explore and develop risk awareness, creativity, and innovation in business and employment-related activities. The development of generic skills among HEI students is focused on teaching and learning through the regular curriculum and co-curricular activities, held in the vicinity of the campus to accommodate residential college students [23].

Students and graduates today need to have skills and capabilities to add values to products, services, and processes in order to compete successfully in business, both locally and globally [24]. According to [25], universities must consider the employability skills of their graduates, equip them with skills for working in both the public and private sectors, and ensure that the unemployed have opportunities to improve their work skills or learn new ones. Graduates of higher education must acquire the generic skills required by the current job market.

\section{Methodology}

The participants in this study are administrators from public and private HEIs in Malaysia. They were chosen for their awareness of the changes in higher education policies as well as their experience in administrative roles. The participants include Vice Chancellors, Directors, Deans, Deputy Deans, and Heads of Departments. The population of this study was 1410 participants from a total of 20 public and 31 private institutions. A sample size of 285 participants was needed, based on the table for determining sample size from a given population by Krejcie \& Morgan [26]. Questionnaires were mailed to 600 respondents, and were distributed personally by the research team. Due to a low return rate, only 306 questionnaires were included in the final analysis; however, this number exceeds the required sample size of 285.

A survey was also used to collect data for this study. It contains questions pertaining to trends in the demand for education by field/program and the importance of generic skills before and after 1995 . The survey was conducted based on the perceptions of the participants, all HEI administrators. In addition, the above_mentioned questionnaire was used. The questionnaire items were developed by the research team using a document analysis technique. Two important documents that were used to identify the items in the questionnaire are The Statistics of Higher Education in Malaysia and Module of Soft Skill Development for HEIs. A pilot test was conducted with 30 participants [27], in order to test the 16 items under two main constructs: demand for education based on field or program (nine items) and generic skills (seven items), The Cronbach's alpha was 0.853, which is high [26].

All 16 items were measured using a seven-point numerical scale [27], with one indicating the least important and seven the most important. Participants were asked to rate the importance of each item before 1995 and after 1995. This year was set as the benchmark for globalization because it is the year Malaysia became a member of the World Trade Organization (WTO). According to [28], liberalization of twelve sectors, including education, was agreed upon. Based on this, 1995 was selected as the year marking the beginning of globalization for the purposes of this study. Respondents were required to compare each item (under the constructs "demand for education based on field or program" and "generic skills") before 1995 and after 1995. The data were then analyzed using descriptive statistics, specifically, by comparing the mean ratings for before and after 1995 in order to identify if there are any significant differences between them. Data were processed using SPSS for Windows Version 18.0. The difference in the mean scores indicates how globalization has affected entrepreneurship education and entrepreneurship skill in HEIs. 


\section{FINDINGS AND DisCUSSION}

Table 1 shows the mean analysis of the demand for education in various fields before and after 1995. The study showed that demand changed in all fields, but the most significant changes are in business and entrepreneurship education, computer science and ICT, and biotechnology and agrotech education. The mean score for business and entrepreneurship education increased from 4.82 before 1995 to 6.23 after 1995 . In addition, the number of HEIs that offer entrepreneurship education has increased. This shows that the demand for business and entrepreneurship education is more widely accepted in society and is encouraging graduates to consider entrepreneurship as a career choice. The mean score increase can be attributed to the heightened awareness that entrepreneurship education contributes to economic growth and also to positive media images of successful entrepreneurs who have served as role models in career selection.

\section{TABLE I: DEMAND FOR EDUCATION BY FIELD/PROGRAM}

\begin{tabular}{|c|c|c|c|c|c|}
\hline \multirow[t]{2}{*}{ Field/Program } & \multirow[t]{2}{*}{$\mathrm{n}$} & \multicolumn{2}{|c|}{ Before 1995} & \multicolumn{2}{|c|}{ After 1995} \\
\hline & & Mean & SD & Mean & SD \\
\hline $\begin{array}{l}\text { Vocational Education (Carpentry, } \\
\text { Automotive, Sewing, etc.) }\end{array}$ & 306 & 4.94 & 1.265 & 5.47 & 1.199 \\
\hline $\begin{array}{l}\text { Technical Education (Electrical, } \\
\text { Engineering) }\end{array}$ & 306 & 5.18 & 1.195 & 5.91 & 0.986 \\
\hline Computers \& ICT Education & 306 & 4.74 & 1.337 & 6.25 & 0.879 \\
\hline $\begin{array}{l}\text { Business \& Entrepreneurship } \\
\text { Education }\end{array}$ & 306 & 4.82 & 1.225 & 6.23 & 0.839 \\
\hline $\begin{array}{l}\text { Education in Professional Fields } \\
\text { (Engineering, Medicine, etc.) }\end{array}$ & 306 & 5.87 & 1.079 & 6.47 & 0.734 \\
\hline Teacher Education & 306 & 5.64 & 1.135 & 6.00 & 1.053 \\
\hline Biotech Education/Agrotech & 306 & 4.26 & 1.418 & 6.02 & 0.996 \\
\hline Social Sciences Education & 306 & 4.97 & 1.162 & 5.46 & 1.218 \\
\hline $\begin{array}{l}\text { Agriculture/Farming Trades } \\
\text { Education }\end{array}$ & 306 & 5.03 & 1.244 & 5.39 & 1.329 \\
\hline
\end{tabular}

Furthermore, research shows that entrepreneurship education can foster an entrepreneurial culture [29]. Indeed, implementation of entrepreneurship education in Malaysia, which is growing in both schools and universities, is aimed at establishing a commercial and industrial community. According to [10], entrepreneurship education includes formal and informal education obtained in schools and HEIs as well as firsthand experience in entrepreneurship and business. The provision of infrastructure and adequate financial resources, qualified academic staff, research and innovation, and lifelong learning are central to the implementation of such education [30].

In addition, awareness of the importance of entrepreneurship education in academic and co-curricular activities is increasing. This has led to a variety of entrepreneurial training programs in HEIs, including an offering of core academic courses, elective courses, entrepreneurial programs, a Bachelor's of Entrepreneurship, and post-graduate courses [4]. Several universities have a special support structure that serves as a center of excellence for small businesses, providing services to students and SME entrepreneurs. These centers include the Entrepreneurship Development Institute at UUM, Malaysia Entrepreneur Development Centre (MEDEC) at UiTM, Small Business
Development Center at the UPM, Bureau of Innovation and Consultancy (BIP) at UTM, and Innovation and Consultancy Centre at USM. Therefore, it is not surprising that entrepreneurial education is one strategy implemented in the Third Outline Perspective Plan (OPP 3rd) with a view to increase the number of skilled human resources as well as foster the ability to develop and promote technological innovation and business to achieve a commercial and industrial community by 2020 [14].

TABLE II: GENERIC SKILLS

\begin{tabular}{lccccc}
\hline & & \multicolumn{2}{c}{ Before } & & \multirow{2}{*}{ After 1995} \\
\cline { 3 - 6 } Generic Skills & $\mathrm{n}$ & & & & \\
& & Mean & SD & Mean & SD \\
\hline Effective communication skills & 306 & 4.77 & 1.318 & 6.34 & 0.787 \\
Problem solving and critical thinking & 306 & 4.86 & 1.352 & 6.41 & 0.802 \\
skills & & & & & \\
Team work skills & 306 & 4.94 & 1.352 & 6.35 & 0.830 \\
Continuous learning and information & 306 & 4.77 & 1.322 & 6.30 & 0.797 \\
management skills & & & & & \\
Entrepreneurial skills & 306 & 4.49 & 1.445 & 6.23 & 0.905 \\
$\begin{array}{l}\text { Ethical and moral professional skills } \\
\text { Management skills }\end{array}$ & 306 & 5.00 & 1.404 & 6.18 & 0.994 \\
Leadership skills & 306 & 4.92 & 1.368 & 6.21 & 0.850 \\
& 306 & 4.99 & 1.394 & 6.27 & 0.844 \\
\hline
\end{tabular}

Table 2 shows the trend of instilling generic skills before and after 1995. The study shows that the trend of instilling generic skills increased after 1995. This indicates that generic skills, also known as soft skills, are currently given more importance in HEIs. The study also found that the category of generic skills that showed the greatest difference in mean score is entrepreneurial skills. Entrepreneurial skills showed a substantial increase in the mean score: from 4.49 before 1995 to 6.23 afterward. This shows that entrepreneurial skills are emphasized in the present and are considered as necessary skills for graduates to be competitive and competent in the global environment. Therefore, the application of generic skills should be implemented comprehensively in universities with the participation of all parties connected with students.

[20] states that in the last two decades, the conditions for job opportunities have changed. This is due to the economic situation in which graduates no longer qualify for jobs based on their academic knowledge; rather, they must have certain characteristics in order to be granted job opportunities. With generic skills, graduates will be more prepared and confident in their job search. The implementation of generic skills education is in line with the second thrust of the National Mission, which states that Malaysia needs to produce human capital with a first class mentality in order to face challenges in the knowledge-based economy and the field of innovation [33].

The findings of this study have significant implications for the implementation of entrepreneurship education in Malaysia. The Ninth Malaysia Plan 2006-2010 emphasized preparing the youth with positive attitudes, knowledge, and skills so as to enable them to face challenges and adjust to the economic changes brought about by globalization [14]. Globalization has forced job seekers in any country to rely not only on academic qualifications, but to equip themselves with skills that will increase their competitiveness in the global market. The development of human capital can be 
achieved by strengthening and improving the performance of HEIs. Therefore, entrepreneurship education should be implemented and offered continuously in order to promote interest in entrepreneurship as a career choice. In addition, it will help develop graduates who are more competitive, knowledgeable, creative, and innovative in the global workforce-world class human capital.

\section{CONCLUSION}

Globalization cannot be suppressed; therefore, it must be faced. Recently, globalization has demanded that HEIs undergo revolutionary changes to ensure human capital is "produced" not for a product-based economy, but for a knowledge-based economy [1]. Human capital is a key national asset in ensuring that the nation can compete and survive in the era of globalization. This is supported by [3], which states that the mind and creativity are the most important assets in the k-economy. Moreover, it is in line with the National Higher Education Strategic Plan 2007-2020, formed in an effort to transform higher education in order to produce human capital with a first class mentality, entrepreneurship education, and entrepreneurial skills. The plan aims to develop human capital to achieve Vision 2020 and successfully face the challenges of globalization.

Entrepreneurs play a significant role in a country's economic growth. They not only introduce new goods and services, but also create more and newer jobs. Entrepreneurship education can be used to raise awareness and open students' minds to entrepreneurship as a viable career choice. An increase in the number of college graduates who enter the field of entrepreneurship is expected to assist Malaysia in fulfilling the five main thrusts outlined in the National Mission for achieving greater success in order to "Build Civilization and Raise the Country's Prestige" [14]. Therefore, HEIs should begin to identify obstacles and constraints that students may encounter in their entrepreneurial activities and to cooperate with successful entrepreneurs to support entrepreneurship acculturation among students entering the workforce.

\section{REFERENCES}

[1] O. Norasmah, K. T .S. Harinder, B. T. Poo and S. Noorasiah, "Globalization and the trend in demand for higher education in Malaysia," International Journal of Education and Information Technologies, vol. 6, pp. 131-140, 2012.

[2] J. W. Moravec, "A new paradigm of knowledge production in higher education," On the Horizon, vol. 3, pp. 123-136, 2008.

[3] I. Rahmah and A. I. Nor, "Globalisasi dan daya saing global: satu tinjauan," in Pembangunan Sumber Manusia dalam era K-Economy, Bangi: Penerbit Universiti Kebangsaan Malaysia, 2007, pp.17-32.

[4] K. H. Mohd and A. W. Syed, Small and Medium-sized Enterprises in Malaysia: Development Issues, Kuala Lumpur: Prentice Hall Pearson, 2002 .

[5] A. Imran, T. Kayhan, R. Kashif-ur, F. A. Jawaria, and A. Ishfaq, "University student's inclination of governance and its effects on entrepreneurial intentions: an empirical analysis," International Journal of Trade, Economics and Finance, vol. 1, pp. 36-39, June, 2010.

[6] Malaysia, The Tenth Malaysia Plan 2011-2015, Kuala Lumpur: Percetakan Nasional, 2010.
[7] Department of Statistics Malaysia, Perangkaan utama tenaga buruh Malaysia, Disember 2010.

[8] C. H. Hoe, "A Prototype to Encourage University Gradutes to Become Franchises," presented at the Persidangan Keusahawanan Kebangsaan Kedua, Hotel Vistana, Pulau Pinang, December 9-10, 2006.

[9] O. Norasmah, H. Halimah, K. Faridah, A. L. P. Zaidatol and A. B. Nor, "Pembentukan indeks tingkah laku keusahawanan golongan remaja Malaysia," Geran Penyelidikan IRPA 07-02-02-0036 EA 279, 2006.

[10] G. Tamizharasi and Dr. N. Panchanatham, "An empirical study of demographic variables on entrepreneurial attitudes," International Journal of Trade, Economics and Finance, vol. 1, no. 2, pp. 215-220, August, 2010.

[11] M. Minniti and M. Lévesque, "Recent developments in the economics of entrepreneurship," Journal of Business Venturing, vol. 23, pp. 603-612, 2008.

[12] Malaysia, The Ninth Malaysia Plan 2006-2010, Kuala Lumpur: Percetakan Nasional, 2006.

[13] D. F. Kuratko and R. M. Hodgetts, Entrepreneurship: Theory, Process and Practice, 6th ed. Mason, Ohio: South-Western, Thomson, 2004

[14] R. D. Hisrich, M. P. Peters and D. A. Shepherd, Entrepreneurship: A Process Perspective, 6th ed. New York: McGraw-Hill Irwin, 2005.

[15] H. Landstrom, "Entrepreneurship research: A missing link in our understanding of the knowledge economy," Journal of Intellectual Capital, vol. 2, pp. 301-322, 2008.

[16] V. H. Fried, "Defining a forum for entrepreneurship scholars," Journal of Business Venturing, vol. 1, pp. 1-11, 2003.

[17] A. Zubaidah and M. Rugayah, "Imperative attributes for graduate employability in manufacturing firms: Issues for internationalizing Malaysia's curricula" in Globalisation and Internationalisation of Higher Education in Malaysia, Penerbit Universiti Sains Malaysia, 2008, pp. 245-260.

[18] O. Norasmah, A. M. A. Ahmad, F. M. J. Mohd, and Z. Ariffin, Entrepreneurial Studies in Higher Education: Methods for Delivering Entrepreneurship Education, UKM, 2008.

[19] Ministry of Higher Education Malaysia, Dasar Pembangunan Keusahawanan Institusi Pengajian Tinggi, Putrajaya: Kementerian Pengajian Tinggi Malaysia, 2010.

[20] Ministry of Higher Education Malaysia, Modul Pembangunan Kemahiran Insaniah (Soft Skills) Untuk Institusi Pengajian Tinggi Malaysia, Serdang: Penerbit UPM, 2006.

[21] N. Norfadhilah and O. Norasmah, "Entrepreneurship program evaluation in polytechnics: teaching staffs' perspectives," in $2 n d$ International Conference on Economics, Trade and Development IPEDR, Bangkok, April 7-8, 2012, pp. 1-6.

[22] B. Prepelita-Raileanu and O. M. Pastae, "Bridging the gap between higher education, academic research and Romanian business community," in Proc. 9th WSEAS Conf. on Education and Education Technology, Japan, Oct 4-6, 2010, pp. 56-61.

[23] Y. P Chua. Kaedah dan statistik penyelidikan: kaedah penyelidikan buku 1, Kuala Lumpur: McGraw Hill Education, 2006.

[24] J. F. Hair, Jr., A. H. Money, P. Samouel and M.Page, Research methods for Business, West Sussex: John Wiley \& Sons Ltd, 2007.

[25] A.Verger, "The merchants of education: global politics and the uneven education liberalization process within WTO," Comparative Education Review, vol . 53, pp. 379- 401, 2009.

[26] W. M. Ladzani and J. J. Vuuren, "Entrepreneurship training for emerging SMEs in South Africa," Journal of Small Business Management, vol. 2, pp. 154-162, 2002.

[27] Ministry of Higher Education Malaysia, The National Higher Education Strategic Pelan Beyond 2020, Putrajaya: Kementerian Pengajian Tinggi Malaysia, 2007.

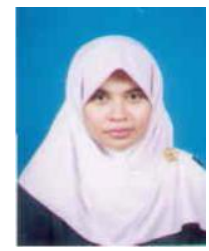

Norasmah Othman is an Associate Professor of Business and Entrepreneurship Education at Universiti Kebangsaan Malaysia, Bangi. She obtained her Ph.D. in Entrepreneurship Education and Assessment from the Universiti Putra Malaysia and her Master's in Finance from the University of New Haven, Connecticut. Her Bachelor's degree is also in the field of Finance, which she obtained from the University of Minnesota, USA. 
Nor Hafiza Othman is presently furthering her studies toward a Master's of Business and Entrepreneurship Education at the Universiti Kebangsaan Malaysia. She obtained her Bachelor of Business Administration (BBA) from Universiti Utara Malaysia.
Rahmah Ismail is a Professor of Economics and Management at Universiti Kebangsaan Malaysia, Bangi. 